DOI: https://doi.org/10.32839/2304-5809/2021-4-92-71

удК 339.7

Татарин Н.Б., Мацей К.П., Скородинський Н.А.

Львівський національний університет імені Івана Франка

\title{
ОСОБЛИВОСТІ ТА НАПРЯМИ РОЗВИТКУ СИСТЕМИ РЕФІНАНСУВАННЯ БАНКІВ В УКРАЇНІ
}

\begin{abstract}
Анотація. У статті розглянуто основні підходи до визначення сутності поняття “рефінансування”, крім цього проаналізовано систему рефінансування банків в Україні на сучасному етапі. Проведено аналіз динаміки показників обсягів наданих коштів через постійно діючу лінію кредитів рефінансування (овернайт), кредитів наданих шляхом проведення тендерів та середніх значень облікової ставки НБУ протягом 2017-2020 років. Проведений аналіз показав, що протягом досліджуваного періоду відбувалося незначні коливання цих показників в сторону зниження або збільшення. Також окреслено основні проблеми, які гальмують розвиток рефінансування банків в Україні. Наведено можливі рекомендації для вдосконалення системи рефінансування банків в Україні та для стимулювання подальшого розвитку національної банківської системи.. Сьогодні ефективне функціонування банківської системи України є неможливим без здійснення певних заходів задля її подальшого розвитку.
\end{abstract}

Ключові слова: банківська система, рефінансування, НБУ, облікова ставка, ліквідність, кредит.

Tataryn Natalia, Matsey Ksenia, Scorodynskyi Nazarii Ivan Franko National University of Lviv

\section{FEATURES ON THE DIRECTIONS OF SYSTEM DEVELOPMENT REFINANCING OF BANKS IN UKRAINE}

Summary. The paper considers the concept of "NBU loans" as a tool for refinancing commercial banks. The article considers the main approaches to defining the essence of the concept of "refinancing", considers the definition and essence of "direct" and reverse repo operations, the main structural elements of the instrument of emergency liquidity support, namely: loan term, loan amount, interest rate, criteria for potential borrowers and the processes of using this tool, in addition, the system of refinancing of banks in Ukraine at the present stage is analyzed. An assessment of the role of refinancing in ensuring the financial security of the banking system of Ukraine was conducted.The role of the NBU and the limits of its influence on the functioning are determined banking sector. The current state of the banking sector of Ukraine is analyzed. An analysis of the dynamics of indicators of the amount of funds provided through the permanent line of refinancing loans (overnight), loans granted through tenders and the average values of the discount rate of the NBU during 2017-2020. The analysis showed that during the study period there were slight fluctuations in these indicators in the direction of decrease or increase. The main problems that hinder the development of bank refinancing in Ukraine are also outlined, in particular the misappropriation of NBU refinancing loans, the use of credit funds for currency speculation, imperfect legislation, the unstable situation in Ukraine and more. The impact of bank refinancing problems on the banking system of Ukraine is determined. Possible recommendations for improving the system of refinancing of banks in Ukraine and for stimulating further development of the national banking system, including improvement of interest rate policy, control over the intended use of funds, disclosure of information on obtaining and repaying loans, etc. The expediency of using these methods and the importance of state policy in regulating the banking sector of Ukraine and their impact on it are substantiated. Today, the effective functioning of the banking system of Ukraine is impossible without the implementation of certain measures for its further development.

Keywords: banking system, refinancing, NBU, discount rate, liquidity, credit.

Постановка проблеми. Сьогодні досить важливе місце у розвитку ринкової економіки займае стабільність банківської системи, яка є одним із головних чинників розвитку економіки будь-якої країни. Рефінансування НБУ є потужним інструментом грошово-кредитної політики, що дозволяе оперативно впливати на управління стабільністю банківської системи

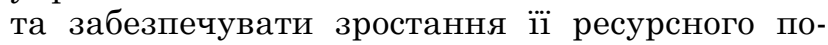
тенціалу. Як свідчить світова практика, система рефінансування та управління ліквідністю банківських систем різних країн знаходяться у постійному розвитку, тому Україні доцільно вдосконалювати наявні та запроваджувати нові механізми рефінансування, що сприятиме забезпеченню стабільності банківської системи в цілому.
Аналіз останніх досліджень та публікацій. Вивченням сутності системи рефінансування та проблем її розвитку займалися багато вітчизняних вчених. Зокрема такі. як В.I. Міщенко, В.В. Коваленко, А.В. Сомик, Г.Г. Фетисов, О.В. Мельниченко, Т.Д. Косова, В.В. Лановий та інші.

Мета та завдання дослідження. Метою статті $е$ дослідження особливостей фрункціонування системи рефінансування банків в Україні, розкриття основних проблем та перспектив їі розвитку, а також визначення рекомендацій для їх вирішення.

Виклад основного матеріалу дослідження. Механізм рефінансування в розпорядженні НБУ е мае значний вплив на розвиток банківської системи України та економіки загалом, тому доцільно детальніше розглянути поняття 
редінансування. Різні вчені трактують це поняття по-різному. Розглянемо деякі з них.

Рефрінансування - це один із основних інструментів грошово-кредитної політики, який використовується центральними банками різних країн. Під рефрінансуванням розуміють забезпечення центральним банком комерційних банків додатковими резервами на кредитній основі, тобто запозиченими резервами. Ініңіаторами рефінансування виступають комерційні банки. Вони звертаються до центрального банку у разі вичерпання можливостей поповнити свої резерви з інших джерел. Рефінансування можна розглядати як процес відновлення ресурсів комерщійних банків, які були вкладені в позики, боргові цінні папери та інші активи [1].

Відповідно до глосарію банківської термінології, рефінансування - це операції з надання банкам кредитів у встановленому національним банком порядку. Основною метою рефінансування $е$ регулювання ліквідності банків на виконання нащіональним банком функщії кредитора останньої інстанції [2].

Кредити НБУ - операщії 3 редрінансування банків та операції з борговими цінними паперами, кредити за інструментом ELA. Національним банк здійснює операції 3 редінансування банків шляхом надання банкам: кредитів овернайт та кредитів шляхом проведення тендерів (рис. 1).

Крім того, Центральний банк може надавати кредити комерційним банкам й через операщії Репо, суть яких полягає в обов'язковій купівлі-продажу державних цінних паперів, проте головною метою цих операцій є підтримка короткострокової ліквідності системи комерційних банків. Національний банк України проводить з банками операції, як «прямого», так й «зворотного» репо на визначену суму та на відповідний термін. «Пряле» репо - це кредитна операція, що грунтуеться на двосторонній угоді між НБУ та банком про купівлю НБУ державних цінних паперів із портфеля банку або іноземної валюти 3 подальшим зобов'язанням банку викупити ці державні цінні папери або іноземну валюту за обумовленою ціною на обумовлену дату. "Зворотне» репо - це депозитна операщія, що трунтуеться на двосторонній угоді між НБУ та банком про продаж НБУ зі свого портфеля 54 державних цінних паперів 3 одночас- ним зобов'язанням зворотного їх викупу в банків 3 обумовленою ціною на обумовлену дату [2].

НБУ запустив у грудні 2016 року замість стабілізаційних кредитів, новий інструмент для підтримки ліквідності банків. Так як даний інструмент було запроваджено не так давно, слід детальніше розглянути його умови (табл. 1).

Для покриття тимчасового дефіциту ліквідності банків у разі настання надзвичайних ситуацій, коли банки вичерпали інші джерела підтримки ліквідності, в тому числі рефінансування НБУ під заставу ОВДП і валюти, а також допомогу акціонерів, можуть скористатись інструментом екстреної підтримки ліквідності - emergency liquidity assistance (ELA).

Для більш детального розуміння стану системи редінансування банків в Україні на сучасному етапі, в першу чергу проаналізуємо середньорічні результати проведення операщій Національного банку України з регулювання ліквідності банків протягом 2017-2020 років (табл. 2).

Відповідно до даних табл. 2 загальний обсяг наданих коштів за 2018 рік становить 181 172,8 млн грн, що на 139319,9 млн грн більше ніж попереднього року: з них кошти, які надані через постійну діючу лінію рефінансування (кредити овернайт) 144 604,3 млн грн, середньозважена ставка яких становила $19,0 \%$, що на 4,4\% вища, ніж у 2017 році; шляхом проведення тендеру з підтримки ліквідності банків 36 568,5 млн грн, у 2017 році 12 799,3, що на 23 769,2 млн грн менше, ніж у 2018 році, середньозважена ставка яких становила у 2017 році - 15,6\%, у 2018 - 19,3\%. Загальний обсяг наданих коштів за 2019 рік становить 102 037,5 млн грн, що на 79 135,3 млн грн менше ніж 2018 року: з них кошти, які надані через постійну діючу лінію рефінансування (кредити овернайт) 39 274,8млн грн, середньозважена ставка яких становила 19,4\%, що практично не відрізняється від попереднього року; шляхом проведення тендеру з підтримки ліквідності банків 62 731,1 млн грн, середньозважена ставка яких становила у 2019 році - 17\%, яка $є$ нижчою на приблизно $2 \%$ в порівнянні з 2018 роком. У 2020 рощі загальний обсяг наданих коштів становить 168 045,5 млн грн, з яких 44213,0 млн грн становлять кредити овернайт

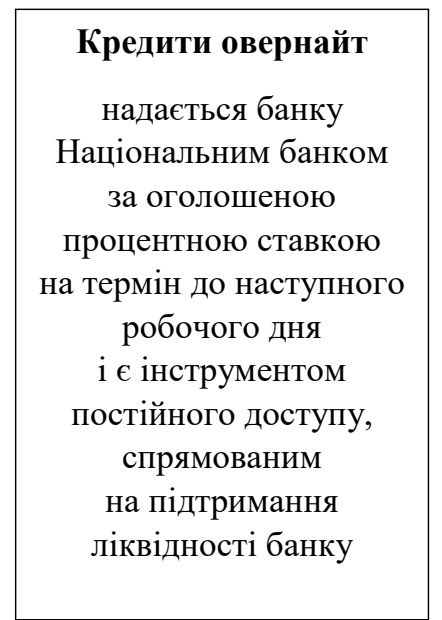

\begin{tabular}{|c|}
\hline Кредитів \\
рефінансування шляхом \\
проведення тендерів \\
із підтримання ліквідності \\
банків строком до 14 днів \\
та строком до 90 днів \\
(короткострокові кредити \\
рефінансування, що \\
надаються банку шляхом \\
проведення кількісного \\
або процентного тендера \\
підтримання ліквідності \\
банків \\
\hline
\end{tabular}

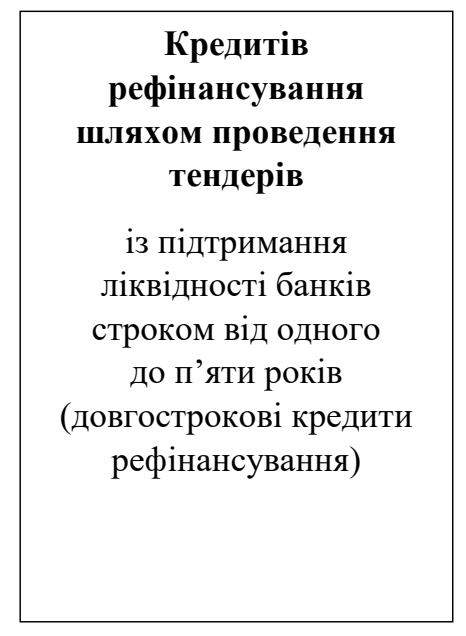

Рис. 1. Кредити Національного банку України 
Екстрена підтримка ліквідності (ELA)

\begin{tabular}{|c|c|}
\hline & Екстрена підтримка ліквідності (ELA) \\
\hline Строк кредиту & $\begin{array}{l}\text { - до } 90 \text { днів } \\
\text { - можливість пролонгацї на строк до } 90 \text { днів } \\
\text { - максимальний строк з урахуванням всіх пролонгацій - } 1 \text { рік }\end{array}$ \\
\hline Сума кредиту & $\begin{array}{l}\text { - на основі прогнозних грошових потоків } \\
\text { - для виконання зобов'язань перед вкладниками та іншими кредиторами } \\
\text { (крім пов'язаних з банком осіб) }\end{array}$ \\
\hline Процентна ставка & $\begin{array}{l}\text { - фріксована щодо кожного траншу } \\
\text { - облікова ставка НБУ }+2 \% \\
\end{array}$ \\
\hline $\begin{array}{l}\text { Критерії (вимоги) до потенційних } \\
\text { позичальників }\end{array}$ & $\begin{array}{l}\text { - банк є платоспроможним (у тому числі у перспективі) } \\
\text { - має вплив на стабільність фінансової системи } \\
\text { - не здійснюе ризикову діяльність }\end{array}$ \\
\hline Процес & $\begin{array}{l}\text { - проведення аналізу та оцінки застави на підготовчому етапі } \\
\text { - швидке надання коштів при виникненні фрактичної потреби в кредиті }\end{array}$ \\
\hline
\end{tabular}

Джерело: розроблено авторами за даними [3]

Результати проведення операцій Національного банку України

Таблиця 2 з регулювання ліквідності банків протягом 2017-2020 рр.

\begin{tabular}{|c|c|c|c|c|c|c|c|}
\hline \multirow{4}{*}{ Дата } & \multicolumn{7}{|c|}{ з підтримання ліквідності банків } \\
\hline & \multirow{2}{*}{$\begin{array}{c}\text { загальний } \\
\text { обсяг } \\
\text { наданих } \\
\text { коштів }\end{array}$} & \multicolumn{3}{|c|}{$\begin{array}{c}\text { через постійно діючу лінію } \\
\text { рефінансування (кредити овернайт) }\end{array}$} & \multicolumn{3}{|c|}{$\begin{array}{c}\text { шляхом проведення тендеру } \\
\text { з підтримання ліквідності банків }\end{array}$} \\
\hline & & $\begin{array}{c}\text { обсяг } \\
\text { наданих } \\
\text { коштів }\end{array}$ & $\begin{array}{l}\text { середньозважена } \\
\text { процентна ставка }\end{array}$ & $\begin{array}{c}\text { к-сть } \\
\text { банків }\end{array}$ & $\begin{array}{c}\text { обсяг } \\
\text { наданих } \\
\text { коштів }\end{array}$ & $\begin{array}{l}\text { середньозважена } \\
\text { процентна ставка }\end{array}$ & $\begin{array}{c}\text { к-сть } \\
\text { банків }\end{array}$ \\
\hline & млн грн & мЛн грн & $\%$ & од. & Млн грн & $\%$ & од. \\
\hline 2017 & 41258,9 & 22933,2 & 15,4 & 1,2 & 12799,3 & 15,6 & 1,3 \\
\hline 2018 & 181172,8 & 144604,3 & 19,0 & 1,3 & 36568,5 & 19,3 & 1,3 \\
\hline 2019 & 102037,5 & 39274,8 & 19,4 & 1,0 & 62731,1 & 17,0 & 2,8 \\
\hline 2020 & 168045,5 & 44213,0 & 8,7 & 1,7 & 65081,0 & 6,0 & 5,2 \\
\hline
\end{tabular}

Джерело: розроблено авторами за даними [4]

та 65 081,0 млн грн становлять кредити надані шляхом проведення тендеру з підтримки ліквідності банків; середньозважені ставки за якими становлять $8,7 \%$ та $6,0 \%$ відповідно, що є значно нижчими у порівнянні з минулими роками.

Отже, підсумовуючи вищесказане, можна зробити висновок, що динаміка щодо питомої ваги кредитів овернайт і кредитів, наданих на тендері у загальній сумі редінансування, протягом 2017 р. частка кредитів овернайт становила $55,6 \%$, а кредитів, наданих на тендері, $-44,4 \%$, 3 наступного 2018 р. частки були відповідно $79,8 \%$ та $20,2 \%$, що чітко видно на рис. 2.
Впродовж 2019-2020 рр. ситуація змінюеться. Наприклад, у 2019 р. частки були відповідно $38,4 \%$ та $61,5 \%$, у 2020 році всього 26,3\% становили кредити овернайт та $73,7 \%$ становили кредити надані шляхом проведення тендеру, що можна пояснити потребою банків протягом 2017-2018 pр. у додаткових к для забезпечення поточної ліквідності та дотримання економічних нормативів, встановлених НБУ.

Окрім цього, важливим показником системи рефрінансування банків в Україні є облікова ставка НБУ. Розглянемо середньорічні значення облікової ставки протягом 2017-2020 рр. (табл. 3).

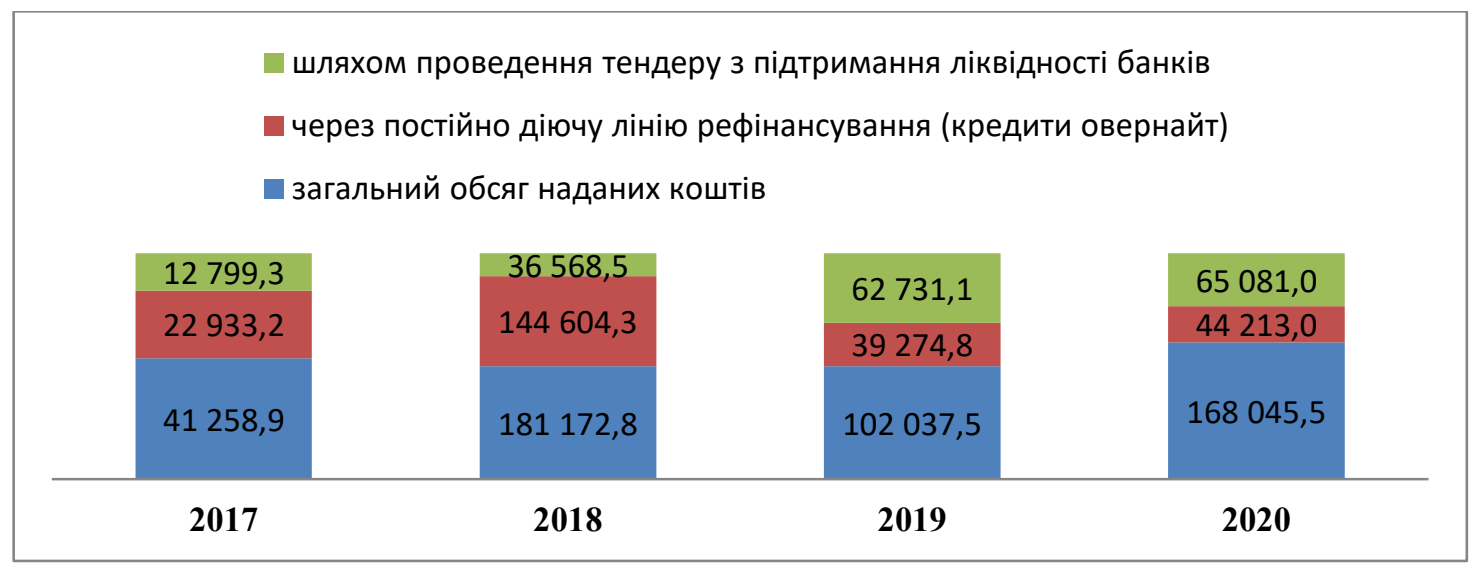

Рис. 2. Результати проведення операцій НБУ з регулювання ліквідності банків 
Таблиця 3

Середньорічні значення облікової ставки НБУ протягом 2017-2020 рр.

\begin{tabular}{|c|c|c|}
\hline Дата & $\begin{array}{c}\text { Облікова ставка } \\
\mathbf{( \% )}\end{array}$ & $\begin{array}{c}\text { Зміна } \\
\mathbf{( \% )}\end{array}$ \\
\hline 2017 & 12,93 & - \\
\hline 2018 & 16,88 & 3,95 \\
\hline 2019 & 17,33 & 0,45 \\
\hline 2020 & 7,57 & $-9,76$ \\
\hline
\end{tabular}

Джерело: розроблено авторами за даними [4]

Облікова ставка НБУ за досліджуваний період зазнавала незначних коливань, в сторону збільшення або зменшення на декілька процентних значень. Також облікова ставка регулярно знижувалася у 2019 році. Загалом із початку року цей показник впав із 18 до 15,5\%. (середне значення протягом року становило майже 17\%). Так, з огляду на значне послаблення інфляційного тиску та скорочення ділової активності впродовж 2020 року, НБУ продовжив пом'якшення монетарної політики. Облікова ставка була знижена до рекордного рівня в $6 \%$ вже у першому півріччі, навіть раніше, ніж передбачалося [2].

Отже, з даних таблиці ми можемо побачити, що найбільшого середнього значення протягом року облікова ставка набула у 2019 році, проте 3 огляду на зменшення інфляційного тиску на економіку НБУ було знижено облікову ставку до $6.0 \%$ у 2020 році.

Важливим напрямом НБУ є взаємодія зі слабкими та неплатоспроможними банками - в такому випадку застосовуються дії, зокрема рефінансування банків для вирішення проблем, одною з яких е ліквідність банківської установи.

Недоліки вітчизняного редінансування, які проявились під час економічної кризи в Україні 2014-2015 рр. та коронакризи ще не є повністю подоланими.

Відповідно, провівши дослідження, можна сказати, що сама дія як рефінансування банківської установи має ряд проблем, які необхідно вирішити.

Серед таких проблем можна виділити такі як:

- забезпечення повернення коштів, враховуючи те, що, будь-яке рефінансування як форма кредитування є ризиковим;

- недостатність уваги з боку Національного банку України до визначення платоспроможності банків, яким надавались кредити рефінансування;

- низький рівень контролю за цільовим використанням коштів;

- використання коштів для валютних спекуляцій на міжбанківському ринку [5].

Таким чином, без подолання вищезазначених проблем ефрективне фрунціонування та стабільний розвиток системи рефінансування та банківської системи України в цілому є неможливим.

Отже, згідно з переліченими проблемами, які спостерігаються в процесі редрінансування банківської системи, можна виділити наступні методи їх вирішення:

- вдосконалення відсоткової політики, зниження процентної ставки, яка буде мати позитивний вплив на доступність позикових коштів;
- застосування ефективної методики оцінювання фінансової стійкості банку, що дозволить зменшити ризик неповернення кредиту;

- контроль за цільовим використанням позикових коштів отриманих від регулятора. Зменшення відсотка можливостей вивезення їх закордон та використання у спекулятивних операціях;

- розкритття інформації про всі надані кредити та їх погашення, що надасть можливість зробити аналіз кредитних операцій НБУ;

- підтримка банків, які кредитують стратегічно важливі програми для держави;

- застосування інструментів рефінансування, які ефективно використовуються в країнах 3 розвиненою економікою [7].

Запропоновані методи для вирішення проблем політики рефінансування матимуть позитивний вплив на вдосконалення механізму редрінансування та сприятимуть стабільному розвитку банківського сектору України в майбутньому.

Висновки. Отже, підсумовуючи все вищесказане щодо сучасного стану системи рефінансування банків України, їі проблем та подальшого вдосконалення, можна зробити висновок, що вітчизняна банківська система має досить великий потенціал розвитку, зокрема в сорері редінансування НБУ комерційних банків, проте важливим кроком є створення сприятливих умов та нових можливостей для цього. Створення розвинутої системи редінансування дасть змогу забезпечити відповідні умови для фрункціонування національної банківської системи та економіки в цілому. Кількісні показники розвитку банківської системи та системи рефінансування України мають достатньо стабільні показники. Крім цього, спостерігається позитивна тенденція щодо скорочення облікової ставки НБУ впродовж 2017-2020 років.

Таким чином, система редінансування банків в Україні знаходиться на етапі розвитку та вдосконалення. Як вже зазначалося, на сьогоднішній день існує ряд проблем, які стримують розвиток та ефрективне функціонування української банківської системи, зокрема нестабільна економічна ситуація в країні, недостатність уваги 3 боку Національного банку України до визначення платоспроможності банків, яким надавались кредити редінансування, низький рівень контролю за цільовим використанням коштів, використання коштів для валютних спекулящій на міжбанківському ринку тощо.

Успішне фонкціонування вітчизняної банківської системи та системи рефрінансування потребуе структурних зрушень та здійснення конкретних заходів задля покращення діяльності та цільового використання коштів комерційними банками, а саме необхідно посилити індивідуальний контроль за роботою керівних органів комерційних банків, які отримали кредити редрінансування вдосконалення відсоткової політики, зниження процентної ставки, яка буде мати позитивний вплив на доступність позикових коштів, застосування механізмів рефінансування, що використовуються розвинутими країнами світу тощо, які дадуть значний поштовх для успішного функціонування банківської системи та економіки України загалом. 


\section{Список літератури:}

1. Глосарій банківської термінології. URL: https://old.bank.gov.ua/control/uk/publish/article?art_id=123491 (дата звернення: 18.04.2021).

2. Офіційний сайт Національного банку України. URL: http://www.bank.gov.ua (дата звернення: 18.04.2021).

3. Екстрена підтримка ліквідності банків (ELA). URL: https://old.bank.gov.ua/doccatalog/document?id= 43242155 (дата звернення: 18.04.2021).

4. Результати проведення операцій Національного банку України з регулювання ліквідності банків. URL: https://bank.gov.ua/ua/markets/liquidity (дата звернення: 19.04.2021).

5. Вдовенко Л.О. Рефінансування як механізм підтримки стабільності банківської системи. Еконоліка. Фінанси. Менеджмент: актуальні питання науки і практики. 2018. № 2.

6. Гаркуша Ю.О. Особливості механізму рефінансування банків в Україні. Глобальні та національні проблели еконоліки. 2016. № 151. URL: http://global-national.in.ua/archive/14-2016/151.pdf (дата звернення: 16.04.2021).

7. Возняковська К.А. Шодо вдосконалення правових механізмів рефрінансування як засобу підтримки національним банком україни слабких та проблемних банків. Вісник Чернівецького ббакультету Національного університету «Одеська юридична акаделія». 2018. № 1.

\section{References:}

1. Glossary of banking terminology. URL: https://old.bank.gov.ua/control/uk/publish/article?art_id=123491

2. Official site of the National Bank of Ukraine. URL: http://www.bank.gov.ua

3. Emergency support for bank liquidity (ELA). URL: https://old.bank.gov.ua/doccatalog/document?id=43242155

4. Results of the National Bank of Ukraine's liquidity regulation operations. URL: https://bank.gov.ua/ua/markets/ liquidity

5. Vdovenko L.O. (2018) Refinancing as a mechanism to maintain the stability of the banking system. Economics. Finance. Management: current issues of science and practice, no. 2.

6. Garkusha Yu.O. (2016) Features of the mechanism of bank refinancing in Ukraine. Global and national economic problems, no. 151. URL: http://global-national.in.ua/archive/14-2016/151.pdf

7. Voznyakovska K.A. (2018) On improvement of legal mechanisms of refinancing as a means of support by the national bank of ukraine for weak and problems. Bulletin of the Chernivtsi Faculty of the National University "Odessa Law Academy", no. 1. 